\title{
ANALISIS HASIL UJI KOMPETENSI GURU SEKOLAH MENENGAH KEJURAN BIDANG KEAHLIAN TEKNIK BANGUNAN
}

\author{
Ahmad Dardiri \\ Mujiyono \\ Mohamad Aris Ichwanto
}

\begin{abstract}
Abstrak: Tujuan penelitian ini untuk mendeskripsikan profil kompetensi guru mencakup: (1) pencapaian kompetensi pedagogik, (2) pencapaian kompetensi profesional, dan (3) menguji apakah ada perbedaan kompetensi kelompok guru adaptif, dan guru produktif berdasarkan latar belakang pendidikan, tingkat pendidikan, dan pengalaman kerja guru Sekolah Menengah Kejuruan (SMK) Bidang Keahlian Teknik Bangunan (BKTB). Penelitian dirancang dengan pendekatan kuantitafif deskriptif terhadap 93 orang guru adaptif dan produktif SMK Kota Blitar. Instrumen yang yang digunakan adalah test kompetensi guru. Hasil penelitian menunjukkan: (1) guru SMK BKTB memiliki kompetensi di atas rata-rata nasional 5,50 namun dibawah ideal nasional 8,00 ; (2) tidak terdapat perbedaan pencapaian kompetensi berdasarkan kelompok adaptif dan produktif.
\end{abstract}

Kata-kata Kunci: kompetensi guru bidang teknik bangunan, SMK

\begin{abstract}
Analysis Achievement Test of Vocational High School Teacher Competency in Civil Engineering Skill Program. The objectives of this study were described teachers competence profile of: (1) achievement of pedagogic competence, (2) achievement of professional competence, and (3) to test whether there is difference of competency of group of adaptive teachers, and productive teachers based on educational background, educational level, and work experence of Vocational High School of Engineering (SMK BKTB). The study was designed with a descriptive quantitative approach to 93 adaptive and productive teachers of SMK Kota Blitar. The instrument used is teacher competency test. The finding showed: (1) SMK BKTB teachers have competencies above the national average of 5.50 but under national ideal 8.00; (2) there is no difference in achievement of competency based on adaptive and productive groups teachers.
\end{abstract}

Keywords: teacher engineering competence, SMK

$\mathrm{S}$ ekolah Menengah Kejuruan (SMK) bertugas menyiapkan sumberdaya manusia berketerampilan tinggisehingga mampu memenangkan persaingan yang amat ketat di era global. Semua komponen SMK memiliki potensi dan tantang- an dalam menyiapkan lulusan yang memiliki daya saing tinggi tersebut. Berdasarkan berbagai kajian dan observasi lapangan ditemukan fakta bahwa lulusan SMK Bidang Teknologi Konstruksi Bangunan (BKTB) belum memiliki daya

Ahmad Dardiri dan Mujiyono adalah Dosen Jurusan Teknik Elektro Universitas Negeri Malang. Email: ahmaddardiri.um@gmail.com. Alamat Kampus: Jl. Semarang No. 5 Malang 65145. Mohamad Aris Ichwanto adalah Mahasiswa S3 Central China Normal University. Alamat Kampus: 152 Luoyu Rd, Hongshan Qu, Wuhan Shi, Hubei Sheng, China, 430072. 
saing yang menggembirakan. Almira, dkk. (2016:674) menyatakan bahwa lulusan SMK BKTB memiliki kendala kesesuaian dengan kebutuhan industri di Jawa Timur. Sebesar $45,50 \%$ lulusan yang terserap di industri jasa konstruksi.

Carina (2015) melaporkan lulusan SMK BKTB yang sesuai dengan kebutuhan industri jasa konstruksi masih rendah. Safitri, dkk. (2012) juga menemukan fakta kompetensi keterampilan dan pengetahuan konstruksi kayu dan keahlian konstruksi baja BKTB masuk kategori tidak relevan. Sudira (2012) menunjukkan kecenderungan umum kompetensi produktif lulusan SMK rendah. Sementara data BPS (2015) menunjukkan masih tingginya angkapengangguran SMK.

Ketidakrelevansian lulusan SMK dengan kebutuhan juga dapat dilihat dari banyaknya lulusan SMK yang tidak bekerja sesuai dengan bidang keahliannya. Dilihat dari aspek proses dan hasil belajar, masih dirasakan kesenjangan relevansi antara lain: (1) kompetensi kurikulum SMK dengan kebutuhan industri; (2) terbatasnya kapasitas SDM industri untuk membimbing Prakerin, (3) belum adanya perencanaan Prakerin oleh industri, (4) belum adanya alokasi biaya untuk pengembangan Prakerin, dan (5) belum terciptanya iklim saling menguntungkan dalam pelaksanaan Prakerin (Mahdiansyah, 2007:24). Hasil studi Ghozali (2004) menemukan perbandingan kompetensi pada jenjang pendidikan kejuruan antara yang dihasilkan oleh sekolah dengan harapan oleh industri/perusahaan. Untuk aspek pengetahuan dan keterampilan, lembaga SMK merasa sudah memberikan pembekalan setinggi 7,92 poin, lulusan/karyawan merasa memilikinya setinggi 7,22 poin, perusahaan menganggap skor pengetahuan dan keterampilan lulusan/karyawan adalah 7,47 poin, dan industri/perusahaan membutuhkan tingkat pengetahuan dan keterampilan lulusan/karyawan yang lebih tinggi, yaitu 8,11 poin.
Berdasarkan pada paparan diatas dapat dikatakan bahwa daya saing lulusan SMK masih rendah. Hal tersebut ditandai dengan rendahnya relevansi kompetensi lulusan sesuai dengan harapan industri/perusahaan.

Guru merupakan elemen penting pendidikan untuk pencapaian tujuan pendidikan. Guru memiliki tugas merencanakan pembelajaran, mengembangkan materi, menetapkan metode dan strategi pembelajaran dan melakukan penilaian. Hariyanto, dkk. (2012:37-46) menunjukkan bahwa pembelajaran kooperatif tipe STAD mampu meningkatkan interaksi proses dan hasil pembelajaran. Hadidjah dan Kusumawardani (2015:189-198) melaporkan peningkatan motivasi belajar mahasiswa dengan penggunaan media animasi yang diciptakan guru. Khoiron dan Sutadji (2012:103-116) memaparkan temuan pengembangan model pembelajaran karakter telah meningkatkan secara signifikan kompeteni kejuruan siswa SMK. Uraian tersebut di atas menggambarkan bahwa guru memiliki peran yang signifikan mencapai tujuan pembelajaran secara efektif. Implikasinya, diperlukan guru-guru yang kreatif, inovatif untuk mengembangkan pembelajaran di SMK PKTB.

Meningkatkan kompetensi siswa SMK diperlukan guru-guru yang profesional. Dalam upaya untuk meningkatkan profesionalisme guru, diperlukan adanya peta yang menggambarkan penguasaan kompetensi dari masing-masing guru. Berpijak dari peta tersebut, akan dikembangkan pelatihan peningkatan profesionalisme guru yang sesuai dengan apa yang dibutuhkan oleh masing-masing guru. Oleh karena itu Kementerian Pendidikan dan Kebudayaan secara terus menerus melakukan pengukuran profesionalisme guru, yaitu dengan Uji Kompetensi Guru (UKG).

Salah satu strategi yang ditawarkan dalam studi ini adalah memetakan 
kompetensi guru Program Keahlian Teknik Bangunan (PKTB) baik kompetensi pedagogik maupun kompetensi profesional. Tujuannya untuk mengetahui level kompetensi individu guru dan peta penguasaan guru pada kompetensi pedagogik dan kompetensi profesional. Kajian hasil UKG dapat mengetahui kelemahan guru SMK PKTB dalam penguasaan kompetensi pedagogik dan profesional .

Masalah yang akan diteliti berkaitan dengan pemetaan hasil UKG berdasarkan variabel latar belakang pendidikan guru, kepangkatan, dan status sertifikasi, pada jenjang pendidikan SMK PKTB kelompok pelajaran Adaptif yaitu Matematika, Fisika, dan kelompok matapelajaran produktif Bidang Teknik Bangunan di Kota Blitar.

Berdasar pada latar belakang masalah tersebut di atas, maka tujuan penelitian ini adalah: (1) memetakan profil kompetensi pedagogik, dan kompetensi profesional guru matematika, fisika, dan produktif keahlian teknik bangunan, (2) adakah perbedaan kompetensi pedagogik guru SMK bidang teknik bangunan pada mata pelajaran Matematika, Fisika, dan Guru Produktif Teknik Bangunan ditinjau dari latar belakang pendidikan guru, kepangkatan, status sertifikasi, kualifikasi akademik, (3) adakah perbedaan kompetensi profesional guru SMK PKTB pada mata pelajaran Matematika, Fisika, dan Mata pelajaran Produktif SMK BKTB ditinjau dari latar belakang pendidikan guru, kepangkatan, status sertifikasi dan kualifikasi akademik.

Urgensi kajian kompetensi guru SMK BKTB untuk menentukan proses pembinaan kompetensi dan profesionalitas guru. Dengan mengetahui peta kompetensi pedagogik dan kompetensi profesional guru SMK BKTB maka jenis pengembangan keprofesionalime berkelanjutan dapat direncanakan dan dilaksanakan dengan tepat. Struktur Kurikulum SMK menunjukkan bahwakompetensi siswa terbentuk melaluikelompok kurikulum adaptif (matematika dan fisika) serta kelompok bidang produktif keahlian teknik bangunan.

Peranan guru sangat menentukan dalam usaha peningkatan mutu pendidikan formal. Guru sebagai agen pembelajaran dituntut untuk mampu menyelenggarakan proses pembelajaran dengan sebaik-baiknya, dalam kerangka pembangunan pendidikan. Guru mempunyai fungsi dan peran yang sangat strategis dalam pembangunan bidang pendidikan, dan oleh karena itu perlu dikembangkan sebagai profesi yang bermartabat. Undang-Undang No. 14 tahun 2005 tentang Guru dan Dosen Pasal 4 menegaskan bahwa guru sebagai agen pembelajaran berfungsi untuk meningkatkan mutu pendidikan nasional. Untuk dapat melaksanakan fungsinya dengan baik, guru wajib untuk memiliki syarat tertentu, salah satu di antaranya adalah kompetensi (Mendiknas RI, 2005).

Penjabaran kompetensi guru yang bertolak dari ketentuan perundangan yang ada (termasuk Keputusan Menteri Pendidikan Nasional yang relevan) perlu diperkaya dengan kajian konseptual dan empirik, mengingat mutu pendidikan merupakan kepedulian global. Kecuali itu kompetensi guru itu perlu dibuktikan dengan penerapannya di lapangan, sehingga pernyataan tentang telah atau belum dikuasainya kompetensi tertentu harus diuji dengan hasil pengamatan kegiatan guru.

Kompetensi guru dapat dimaknai sebagai kebulatan pengetahuan, keterampilan dan sikap yang berwujud tindakan cerdas dan penuh tanggung jawab dalam melaksanakan tugas sebagai agen pembelajaran. Kompetensi pedagogik seorang guru ditandai dengan kemampuannya menyelenggarakan proses pembelajaran yang bermutu, serta sikap dan tindakan yang dapat dijadikan teladan. Guru juga perlu memiliki kompetensi profesional yaitu selalu meningkatkan dan 
mengembangkan kualifikasi akademik dan kompetensi secara berkelanjutan sejalan dengan perkembangan ilmu pengetahuan, teknologi, dan seni.

Kompetensi pedagogik merupakan salah satu jenis kompetensi yang mutlak harus dikuasai guru. Kompetensi ini pada dasarnya adalah kemampuan guru dalam mengelola pembelajaran yang merupakan kompetensi khas, yang akan membedakan guru dengan profesi lainnya dan akan menentukan tingkat keberhasilan proses dan hasil pembelajaran. Sedangkan kompetensi profesional adalah bidang studi yang diujikan sesuai dengan bidang studi sertifikasi sedangkan bagi guru yang belum sertifikasi disesuaikan dengan kualifikasi akademik guru.

Undang-Undang Republik Indonesia Nomor 20 Tahun 2003 tentang Sistem Pendidikan Nasional, pasal 18 dan penjelasan pasal 15 dalam UU No. 20 tahun 2003 Pendidikan Nasional mengatur pendidikan menengah kejuruan. Pasal 18 ayat 1 menyatakan bahwa pendidikan menengah merupakan lanjutan pendidikan dasar; ayat 2 menyatakan pendidikan menengah terdiri atas pendidikan menengah umum dan pendidikan menengah kejuruan; ayat 3 menyatakan bahwa salah satu bentuk pendidikan menengah adalah SMK (Mendiknas RI, 2003).

Seiring dengan bergulirnya era global dan perkembangan ilmu pengetahuan yang begitu cepat, pendidikan kejuruan dihadapkan pada berbagai permasalahan menyangkut kualitas lulusan yang dihasilkannya. Keluhan muncul dari dunia kerja bahwa lulusan yang memasuki dunia kerja belum memiliki kesiapan kerja yang baik. Sistem pendidikan yang selama ini diterapkan dirasakan belum mampu menghasilkan kualitas sumberdaya manusia yang mampu bersaing di era global, serta kurang mendukung tuntutan dunia usaha/industri akan kebutuhan tenaga kerja.
Pada peradaban bangsa mana pun, termasuk Indonesia, profesi guru bermakna strategis, karena penyandangnya mengemban tugas sejati bagi proses kemanusiaan, pemanusiaan, pencerdasan, pembudayaan, dan pembangun karakter bangsa. Undang-undang RI Nomor 14 Tahun 2005 tentang Guru dan Dosen Pasal (8) mengamanatkan bahwa guru wajib memiliki kualifikasi akademik, kompetensi, sertifikat pendidik, sehat jasmani dan rohani, serta memiliki kemampuan untuk mewujudkan tujuan pendidikan nasional (Mendiknas RI, 2005).

Kompetensi kinerja profesi keguruan dalam penampilan aktual proses belajar mengajar, minimal memiliki empat kemampuan: (1) merencanakan proses belajar-mengajar; (2) melaksanakan dan memimpin/mengelola proses belajarmengajar; (3) menilai kemajuan proses belajar-mengajar; dan (4) menguasai bahan pelajaran. Penguasaan guru akan bahan pelajaran (berdasarkan kurikulum) sangat berpengaruh terhadap hasil belajar siswa. Hasil penelitian di Indonesia menunjukkan bahwa $26,17 \%$ dari hasil belajar siswa dipengaruhi oleh penguasaan guru dalam hal materi pelajaran (Saud, 2009).

\section{METODE}

Penelitian ini dirancang dengan pendekatan penelitian deskriptif kuantitatif Populasi dan sampel penelitian ditetapkan secara purposif sampling pada 93 orang guru tiga SMK PKTB Kota Blitar yaitu SMK Negeri 1 Blitar, SMK Islam Blitar, dan SMK Katolik Kota Blitar. Pengambilan sampel dilakukan secara purposive pada semua guru normative dan produktif tersebut dimaksudkan untuk memperoleh informasi riil pencapaian kompetensi guru SMK PKTB secara detail. Teknik analisis data yang digunakan statistik Deskriptif dan One way Anova. 


\section{HASIL}

Profil Kompetensi Guru dapat dijelaskan sebagai berikut, kompetensi pedagogik dan komptensi profesional guru SMK BKTB dipaparkan pada Diagram 1. Rerata skorkompetensi pedagogik guru matematika sebesar 51,62; guru fisika 84,52; guru bidang studi Teknik Bangun- data Uji Kompetensi guru SMK BKTB dipaparkan pada Tabel 2. Dari Tabel 2 tersebut dapat diketahui informasi sebagai berikut. (1) Hasil uji Kompetensi Pedagogik nilai rerata sebesar 56,72; standar deviasi 17,96; maksimum 100 dan, minimum 15,87; dan varian sebesar 322,65; (2) Hasil Uji Kompetensi

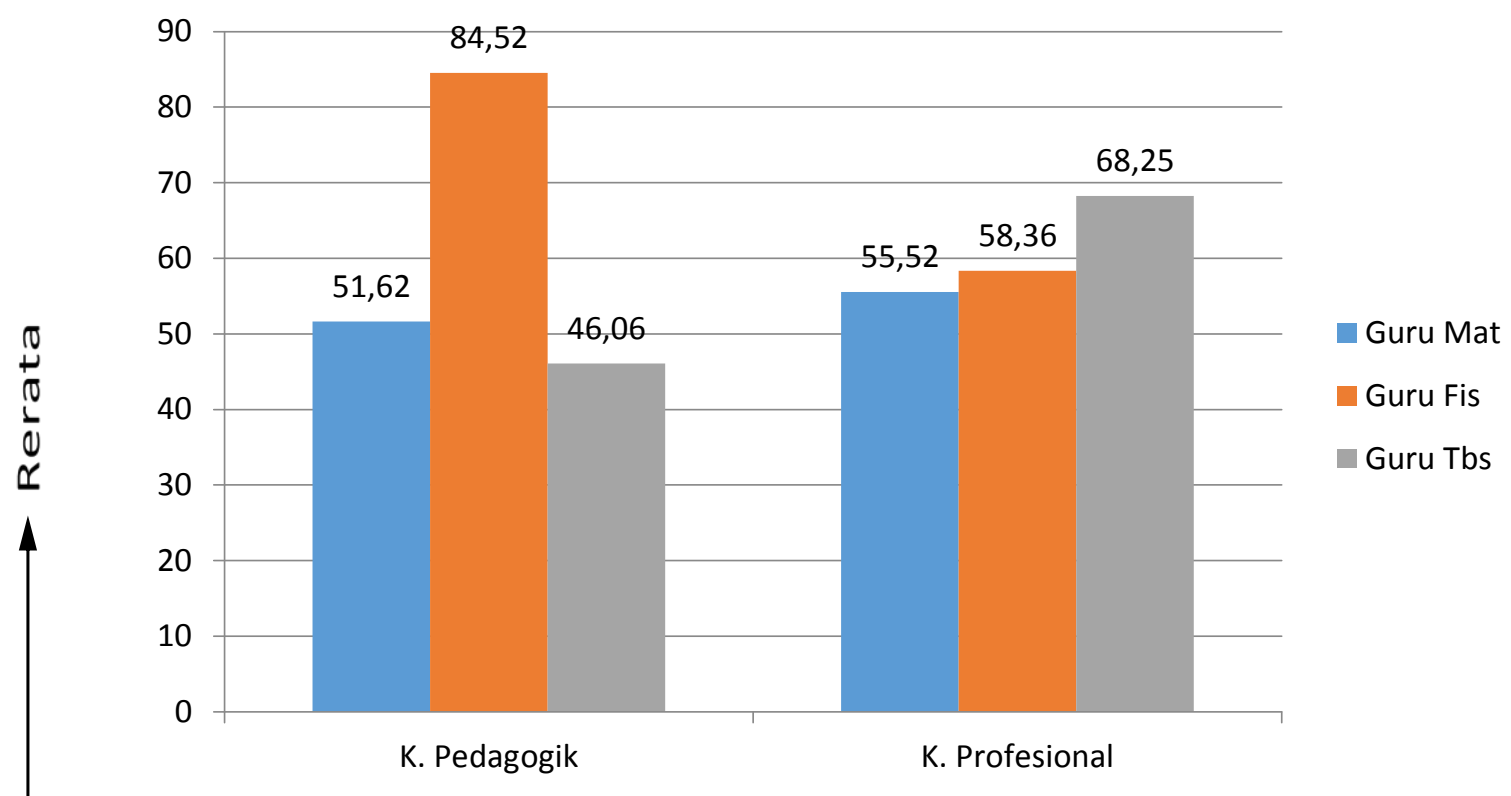

Diagram 1. Pencapaian Rerata Kompetensi Pedagogik dan Kompetensi Profesional

Tabel 1. Data Hasil Analisis Descriptive Uji Kompetensi Guru Teknik Bangunan SMK Blitar

\begin{tabular}{|c|c|c|c|c|c|c|c|c|c|}
\hline Kompetensi & $\mathbf{N}$ & $\begin{array}{l}\text { Ren- } \\
\text { tang }\end{array}$ & $\begin{array}{l}\text { Mini- } \\
\text { mum }\end{array}$ & $\begin{array}{c}\text { Maksi- } \\
\text { mum }\end{array}$ & Jumlah & Rera & & SD & Variasi \\
\hline & Statistil & Statistik & Statistik & Statistik & Statistik & Statistik & SE & Statistik & Statistik \\
\hline Pedagogik & 93 & 84,13 & 15,87 & 100,00 & 5274,55 & 56,72 & 1,86 & 17,96 & 322,65 \\
\hline Profesional & 93 & 68,03 & 27,21 & 95,24 & 5415,14 & 58,23 & 1,58 & 15,26 & 233,01 \\
\hline $\begin{array}{l}\text { Valid N } \\
\text { (listwise) }\end{array}$ & 93 & & & & & & & & \\
\hline
\end{tabular}

an sebesar 46,05; rerata skor kompetensi profesional guru matematika 55,52; guru Fisika 58,36; dan guru bidang studi Teknik Kosntruksi Bangunan 68,25. Secara lengkap deskripsi kompetensi guru SMK Teknik Bidang Keahlian Teknik Bangunan dipaparkan Tabel 1.

Kompetensi guru matematika dapat dijelaskan sebagai berikut, hasil analisis
Profesional nilai rerata sebesar 58,23; standar deviasi sebesar 15,26, nilai maksimum 95,24, minumum 27,21 ; dan varian sebesar 233,011.

Hasil uji kompetensi pedagogik guru matematika SMK BKTB Blitar dapat dipaparkan pada Tabel 2. Kompetensi pedagogik, rerata sebesar 51,65; nilai SD sebesar 12,53; maksimum se- 
besar 95,24; dan minimuam sebesar 18.83, sedangkan varian sebesar 156 , 91; (2) Kompetensi profesional mean sebesar 55,52, SD sebesar 15,56, maksimum 95,24; minimum sebesar 25,40, dan varian sebesar 274,43 . Sedangkan pencapaian skor uji kompetensi guru matematika diuraikan pada Tabel 3 dengan kategori baik (81-100) 1 orang $(1,67 \%)$, kategori cukup (56-80) 21 orang (35\%), dan kategori rendah (15-55) 38 orang $(63,33 \%)$. Tabel 2.Hasil Uji Kompetensi Guru Matematika. skor ujikompetensi guru fisika dipaparkan pada Tabel 5. Kategori baik skor (81-100) dicapai 1 orang (2,00\%), Kategori cukup skor (56-80) dicapai 25 orang $(50 \%)$,sedangkan skor kurang (15-55) dicapai oleh 24 orang $(48 \%)$.

Hasil uji kompetensi pedagogik guru produktif SMK BKTB dapat dipaparkan pada Tabel 6. Hasil Uji Kompetensi pedagogik guru produktif memiliki rerata 58,47, $\mathrm{SD}=18,08$; maksimum 62 , 60; minimum 26,46; varian sebesar 328, 83. Kompetensi profesional guru produk-

Tabel 2.Hasil Uji Kompetensi Guru Matematika

\begin{tabular}{lccccccc}
\hline & N & Rentang & Minimum & Maksimum & Rerata & SD & Variasi \\
\hline Pedagogik & 70 & 79,37 & 18,83 & 95,24 & 51,65 & 12,53 & 156,91 \\
Profesional & 70 & 68,03 & 25,4 & 95,24 & 55,52 & 16,56 & 274,43 \\
\hline
\end{tabular}

Tabel 3. Distribusi Frekuensi Skor Uji Kompetensi Guru Matematika

\begin{tabular}{lccc}
\hline Kategori & Skor & Frekuensi & Persentase \\
\hline Baik & $81-100$ & 1 & 1.67 \\
Cukup & $56-80$ & 21 & 35.00 \\
Kurang & $15-55$ & 38 & 63.33 \\
Jumlah & & 60 & 100.00 \\
\hline
\end{tabular}

tif mencapai rerata 56,$62 ; \mathrm{SD} 47,62$, maksimum sebesar 87,70 minimum sebesar 27, 21, SD =47,62, dan varian sebesar 224.35. Distribusi skor pencapaian kompetensi diuraikan pada Tabel 7. Kategori baik skor (81-100) dicapai oleh dua orang guru $(12,20 \%)$, skor kategori

Tabel 4. Kompetensi Guru Fisika

\begin{tabular}{lccccccc}
\hline Kompetensi & N & Rentang & Minimum & Maksimum & Rerata & SD & Variasi \\
\hline Pedagogik & 50 & 35,19 & 64,81 & 100 & 84,3 & 12,18 & 148,33 \\
Profesional & 50 & 28,5 & 45,63 & 71,4 & 58,36 & 8,12 & 65,95 \\
\hline
\end{tabular}

Tabel 5. Distribusi Frekuensi Skor Uji Kompetensi Guru Fisika

\begin{tabular}{lccc}
\hline Kategori & Skor & Frekuensi & Persentasi \\
\hline Baik & $81-100$ & 1 & 2,00 \\
Cukup & $56-80$ & 25 & 50,00 \\
Kurang & $15-55$ & 24 & 48,00 \\
Junlah & & 50 & 100,00 \\
\hline
\end{tabular}

cukup (56-80) dicapai 12 orang (75\%) dan kategori kurang diperoleh dua orang $(12,50 \%)$

Hasil uji kompetensi guru SMK Teknik Bangunan Blitar berdasarkan pada pendidikan sarjana dipaparkan pada Tabel 8. Kompetensi Pedagogik memper-

Tabel 6. Hasil Uji Kompetensi Guru Produktif

\begin{tabular}{lccccccc}
\hline Kompetensi & N & Rentang & Minimum & Maksimum & Rerata & SD & Variasi \\
\hline Pedagogik & 16 & 35,19 & 26,46 & 62,6 & 58,47 & 18,08 & 326,83 \\
Profesional & 16 & 28,8 & 27,21 & 87,7 & 56,67 & 47,62 & 224,35 \\
\hline
\end{tabular}

Hasil uji kompetensi pedagogik guru fisika SMK BKTB dipaparkan pada Tabel 4. Rerata 84,30, SD =12,18, Maksimum $=100$, Minimum $=64,81$, Varian $=148,33$. Distribusi Frekuensi oleh skor mean sebesar 54,66; SD sebesar 16,14; maksimum sebesar 100; dan minimum sebesar 21,87; sedangkan varian sebesar 260,45; (2) Kompetensi Profesional memperleh skor mean se- 
Tabel 7. Distribusi Frekuensi Skor Uji Kompetensi Guru Produktif

\begin{tabular}{lccc}
\hline Kategori & Skor & Frekuensi & Persentase \\
\hline Baik & $81-100$ & 2 & 12,50 \\
Cukup & $56-80$ & 12 & 75,00 \\
Kurang & $15-55$ & 2 & 12,50 \\
Jumlah & & 16 & 100,00 \\
\hline
\end{tabular}

$\mathrm{M}=61.62 ; \mathrm{SD}=12,88) ; \mathrm{t}(74)=-2,94 ; \mathrm{p}$ $<0,05$. Analisis berdasarkan latar belakang pendidikan yaitu lulusan kependidikan dan non kependidikan (murni) pada tes UKG SMK. Adapun hasil analisis statistik nya dijelaskan pada Tabel 10.

Tabel 8. Hasil UKG SMK TB Menurut Pendidikan S1/D4 (Sarjana)

\begin{tabular}{lccccccc}
\hline Kompetensi & N & Rentang & Minimum & Maksimum & Rerata & SD & Variasi \\
\hline Pedagogik & 65 & 78,84 & 21,6 & 100 & 54,66 & 16.14 .43 & 260,5 \\
Profesional & 65 & 63,49 & 27,21 & 90,7 & 59,06 & 47,62 & 208,16 \\
\hline
\end{tabular}

Tabel 9. Kompetensi Guru Berdasarkan Pendidikan S2

\begin{tabular}{lccccccc}
\hline Kompetensi & N & Range & Minimum & Maximum & Mean & SD & Variance \\
\hline Pedagogik & 11 & 52,91 & 42,33 & 100 & 59,33 & 16,04 & 257,31 \\
Profesional & 11 & 56,69 & 38,55 & 90,7 & 59,86 & 17,55 & 308,03 \\
\hline
\end{tabular}

Tabel 10 . Hasil Uji Kompetensi Berdasarkan Perbedaan Latar Belakang Bidang Keilmuan Pendidikan Guru

\begin{tabular}{lccccc}
\hline \multirow{2}{*}{ Kompetensi } & \multicolumn{2}{c}{ Lulusan kependidikan } & \multicolumn{2}{c}{ Lulusan Non Kependidikan } & \multirow{2}{*}{ T test } \\
\cline { 2 - 5 } & $\mathbf{n}$ & $\mathbf{M ~ ( S D )}$ & $\mathbf{n}$ & $\mathbf{M}(\mathbf{S D})$ & \\
\hline Pedagogik & 48 & $52,01(14,47)$ & 28 & $61,06(17,38)$ & 0,291 \\
Profesional & 48 & $58,08(15,01)$ & 28 & $61,06(14,48)$ & 0,778 \\
\hline
\end{tabular}

besar 59,06, SD sebesar 14,43 maksimum 90,70, minimum sebesar 27,21, dan varian sebesar 208,16.

Kompetensui guru menurut pendidikan S2 dapat dijelaskan sebagai berikut. Hasil uji kompetensi SMK BKTB menurut Pendidikan S2 dipaparkan pada Tabel 9. Kompetensi Pedagogik skor mean sebesar 59,33; SD sebesar 16,04; Maksimum sebesar 95,04; dan minimum sebesar 42,33; sedangkan Varian sebesar 257,31. Kompetensi Profesional guru berdasarkan latar pendidikan Magister Mean sebesar 59,86; SD sebesar 17,55 Maksimum 95,24; minimum sebesar 38,55; dan varian sebesar 308,03.

Perbedaan Kompetensi profesional guru adaptif dan guru produktif dapat dijelaskan sebagai berikut, berdasarkan hasil statistik pada tabel 1 menunjukkan bahwa kemampuan profesional guru adaptif $(\mathrm{N}=59 ; \mathrm{M}=56.61 ; \mathrm{SD}=14.39)$ tidak berbeda signifikan dengan kemampuan profesional guru produktif $(\mathrm{N}=17$;
Perbedaan Hasil Uji Kompetensi Pedagogik antara Guru Lulusan bidang Kependidikan dan Lulusan Non Kependidikan dapat dijelaskan sebagai berikut. Berdasarkan hasil statistik pada Tabel 11 menunjukan bahwa kompetensi pedagogik guru lulusan bidang kependidikan $(\mathrm{N}=48 ;, \mathrm{M}=52.01 ; \mathrm{SD}=14.47)$ tidak berbeda signifikan dengan kemampuan pedagogik guru lulusan non kependidikan $(\mathrm{N}=28 ; \mathrm{M}=61.06 ; \mathrm{SD}=17.38)$; $\mathrm{t}(74)=-2.44 ; \mathrm{p}<0,05$.

Berdasarkan hasil statistik pada Tabel 10 menunjukan bahwa kemampuan profesional guru lulusan kependidikan $(\mathrm{N}=48, \mathrm{M}=56.26, \mathrm{SD}=12.06)$ tidak berbeda signifikan dengan kemampuan profesional guru lulusan non kependidikan $(\mathrm{N}=28, \mathrm{M}=61.06, \mathrm{SD}=14.48), \mathrm{t}(74)=$ $-8.46, \mathrm{p}<.05$.

Kompetensi Guru Bedasar Status Sertifikasi dapat dijelaskan sebagai berikut, analisis perbedaan nilai kompetensi pedagogik dan kompetensi profesional, 
Tabel 11. T-test Perbedaan Status Sertifikasi

\begin{tabular}{llcccc}
\hline \multirow{2}{*}{ Kompetensi } & \multicolumn{2}{l}{ Bersertifikat Pendidik } & \multicolumn{2}{c}{ Belum Bersertifikat Pendidik } & \multirow{2}{*}{ T test } \\
\cline { 2 - 5 } & $\mathbf{n}$ & $\mathbf{M}(\mathbf{S D})$ & $\mathbf{n}$ & $\mathbf{M}($ SD) & \\
\hline Pedagogik & 69 & $54,01(15,48)$ & 7 & $68,44(17,49)$ & 0,684 \\
Profesional & 69 & $58,75(14,19)$ & 7 & $63,40(20,71)$ & 0,266 \\
\hline
\end{tabular}

Tabel 12. Perbedaan Kualifikasi Akademik

\begin{tabular}{|c|c|c|c|c|c|}
\hline \multirow{2}{*}{ Kompetensi } & \multicolumn{2}{|c|}{ Lulusan S1/D4 } & \multicolumn{2}{|r|}{ Lulusan S2 } & \multirow{2}{*}{ T test } \\
\hline & $\mathbf{n}$ & M (SD) & $\mathbf{n}$ & M (SD) & \\
\hline Pedagogik & 65 & $54,67(16,14)$ & 11 & $59,33(16,04)$ & 0,804 \\
\hline Profesional & 65 & $59,06(14,43)$ & 11 & $59,86(17,55)$ & 0,370 \\
\hline
\end{tabular}

Tabel 13. T-test Perbedaan Berdasarkan Status Sekolah

\begin{tabular}{lccccc}
\hline \multirow{2}{*}{ Kompetensi } & \multicolumn{2}{c}{ Sekolah Negeri } & \multicolumn{2}{c}{ Sekolah Swasta } & \multirow{2}{*}{ T test } \\
\cline { 2 - 5 } & $\mathbf{n}$ & $\mathbf{M}($ SD) & n & M (SD) & \multirow{2}{*}{0,075} \\
\hline Pedagogik & 44 & $57,44(18,11)$ & 32 & $52,46(12,56)$ & 0,0756 \\
Profesional & 44 & $60,11(14,85)$ & 32 & $57,89(14,84)$ & 0,956 \\
\hline
\end{tabular}

guru SMK BKTB berdasarkan status guru bersertifikat pendidik dan guru yang belum bersertifikat pendidik pada tes UKG SMK dipaparkan pada Tabel 11.

Berdasarkan hasil statistik pada Tabel 9 menunjukan bahwa kemampuan pedagogik guru bersertifikat pendidik $(\mathrm{N}=$ 69; $\mathrm{M}=54,01 ; \mathrm{SD}=15,48)$ tidak berbeda signifikan dengan kemampuan pedagogik guru yang belum bersertifikat pendidik $(\mathrm{N}=7 ; \mathrm{M}=68,44 ; \mathrm{SD}=17,49) ; \mathrm{t}(74)=-$ 2,$32 ; \mathrm{p}<0,05$.

Berdasarkan hasil statistik pada Tabel 11 menunjukan bahwa kemampuan profesional guru yang telah bersertifikat pendidik $(\mathrm{N}=69 ; \mathrm{M}=58,75 ; \mathrm{SD}=14,19)$ tidak berbeda signifikan dengan kemampuan profesional guru yang belum bersertifikat pendidik $(\mathrm{N}=7 ; \mathrm{M}=63,40$; $\mathrm{SD}=20,71) ; \mathrm{t}(74)=-0,791 ; \mathrm{p}<0,05$.

Hasil Uji Kompetensi Guru SMK BKTB berdasarkan Kualifikasi Akademik dapat dijelaskan sebagai berikut. Analisis perbedaan nilai kompetensi pedagogik, kompetensi profesional guru SMK berdasarkan kualifikasi akademik guru yaitu guru lulusan Stratal (S1) atau Diploma 4 (D4) dan guru lulusan Strata 2 atau lebih pada tes UKG SMK di peroleh adalah sebagai Tabel 10.Berdasarkan ha- sil statistik pada Tabel 10 menunjukkan bahwa kemampuan pedagogik guru lulusan Strata1 (S1) atau Diploma 4 (D4) $(\mathrm{N}=65 ; \mathrm{M}=54,67 ; \mathrm{SD}=16,14)$ tidak berbeda signifikan dengan kemampuan pedagogik guru lulusan Strata 2 atau lebih $(\mathrm{N}=11 ; \mathrm{M}=59,33 ; \mathrm{SD}=16,04) ; \mathrm{t}(74)=$ $-0,804 ; \mathrm{p}<0,05$.

Berdasarkan hasil statistik pada Tabel 12 menunjukan bahwa kemampuan profesional guru lulusan Strata1 (S1) atau Diploma 4 (D4) $(\mathrm{N}=65 ; M=59,06 ; S D=$ 14,43) tidak berbeda signifikan dengan kemampuan profesional guru lulusan Strata $2(\mathrm{~N}=11 ;$ Mean $=59,86 ; S D=$ $17,55) ; \mathrm{t}(74)=-0,164 ; \mathrm{p}<0,05$.

Perbedaan Kompetensi Guru Berdasarkan Status Sekolah dapat dijelaskan sebagai berikut. Berdasarkan hasil statistik pada Tabel 13 menunjukan bahwa kemampuan pedagogik guru sekolah negeri $(\mathrm{N}=44, M=57,44 ; S D=18,11)$ tidak berbeda signifikan dengan kemampuan pedagogik dan guru sekolah swasta $(\mathrm{N}=33$, $M=52,46 ; S D=12,56) ; \mathrm{t}(74)=1,338 ; \mathrm{p}$ $<0,05$.

Berdasarkan hasil statistik pada tabel 13 menunjukan bahwa kemampuan profesional guru sekolah negeri $(\mathrm{N}=44, M$ $=60.11, S D=14.85)$ tidak berbeda signi- 
fikan dengan kemampuan profesional dan guru sekolah swasta $(\mathrm{N}=33$, $M=57,89 ; \quad S D=14,84) ; \mathrm{t}(74)=0,646 ; \mathrm{p}$ $<0,05$.

\section{PEMBAHASAN}

Hasil penelitian menunjukkan bahwa kompetensi pedagogik mencapai skor 56,71, Kompetensi Profesional 58,23. Hal tersebut memberi gambaran bahwa kompetensi guru SMK Teknik Bangunan di Blitar memiliki skor di atas standar nasional tahun 2016yaitu 5,50. Namun demikian masih jauh dari kondisi ideal yang ditetapkan yaitu 80. Bianome (2016) melaporkan bahwa profesionalisme guru produktif SMK dipengaruhi oleh kepemimpinan kepala sekolah dan iklim organisasi di sekolah. Suyitno dkk. (2014), Dardiri (2015) menunjukkan bahwa kepemimpinan entrepreneur kepala sekolah memberikan dampak bagi kinerja pendidikan.

Secara parsial diperoleh fakta bahwa masih banyak guru-guru yang memiliki kompetensi pedagogik dan kompetensi profesional di bawah standar kelulusan yang ditetapkan secara nasional. Hal tersebut memiliki makna bahwa guruguru masih perlu dilakukan penyegaran dan pelatihan terkait dengan kompetensi pedagogis dan kompetensi profesional khususnya guru matematik dan guru produktif. Guru-guru kurang memiliki pengalaman dalam mengembangkan pembelajaran inovatif, sehingga soal-soal yang dibuat dalam UKG kurang dapat dipahami oleh para guru.

Hal ini perlu menjadi perhatian bagi pengelola dan pengembangan profesionalitas guru khusunya kompetensi pedagogis maupun kompetensi profesional. Hasil temuan penelitian juga menunjukkan bahwa latar belakang bidang keilmuan, tingkat pedidikan, status sekolah (negeri dan swasta) tidak memiliki perbedaan signifikan terhadap pencapaian uji kom- petensi pedagogik dan uji kompetensi profesional. Hal tersebut memungkinkan terjadi jika guru tidak termotivasi untuk melakukan inovasi pembelajaran. Motivasi guru akan tumbuh jika mereka memperoleh pengakuan/penghargaan sesuai dengan prestasinya.

Memberikan motivasi guru untuk melakukan inovasi pembelajaran merupakan tugas kepala sekolah. Melalui kegiatan supervisi pembelajaran kepala sekolah memberikan masukan-masukan untuk memperbaiki mutu pembelajaran. Fakta di lapangan menunjukkan kepala sekolah jarang melakukan supervisi di kelas saat guru melakukan pembelajaran. Ernawati dan Marjono (2007) menunjukkan supervisi dan kedisiplinan kepala sekolah berpengaruh pada kinerja guru. Sujianto, dkk. (2012) melaporkan bahwa kinerja guru SMK bersertifikat pendidik masih rendah. Rahman (2009) menegaskan upaya peningkatan kualitas guru tidak cukuphanya diberikan gaji tinggi, tetapi perlu pembinaan berkelanjutan.

Berdasar hasil wawancara dengan para guru diperoleh informasi bahwa bahasa yang digunakan untuk soal UKG pada aspek kompetensi pedagogik terlalu teoritik sehingga istilah yang digunakan tidak dikenali oleh para guru. Para guru juga mengalami kendala pada saat mengerjakan soal kompetensi profesional karena ditemukan banyak soal yang tidak ada pilihan jawaban yang benar. Sebagai contoh test Matematika yang menanyakan berapa $\log 8$ dalam option jawaban tidak didapat pilihan jawaban yang benar sehingga. Seorang guru matematika mengungkapkan keluhan bahwa dia sudah menjadi guru lebih dari 10 tahun untuk menghitung matematika $\log 8$ saja kok tidak bisa.

Kendala yang dihadapi guru produktif dalam menjawab soal ujian kompetensi guru antara lain tidak jelasnya kisi-kisi materi soal yang akan diujikan. Materi terlalu luas kurang fokus. Sebagai 
contoh di petunjuk hanya disebutkan materi tentang beton. Para guru melihat lingkup pekerjaan beton terlalu luas $\mathrm{ku}-$ rang fokus pada persoalan yang lebih spesifik tentang bagian-bagian beton. Pada sisi lain soal yang diberikan terlalu tinggi (sulit) untuk kompetensi guru yang mengajar beton di SMK. Kendala lain yang dirasakan guru SMK Program Keahlian Konstruksi Bangunan terutama guru yang senior kurang bisa mengikuti perkembangan teknologi/model-model pembelajaran.

\section{SIMPULAN DAN SARAN}

Berdasarkan hasil analisis dan pembahasan menunjukkan: (1) kompetensi pedagogik guru SMK BKTB memperoleh rerata 56,71 ; (2) kompetensi profesional guru SMK BKTB memperoleh skor rerata 58,23; dan (3) tidak terdapat perbedaan yang signifikan hasil uji kompetensi pedagogik maupun kompetensi profesional guru ditinjau dari kepangkatan, kualifikasi akademik, kelompok keilmuan, dan status sekolah.

Berdasarkan hasil dan pembahasan disarankan agar kepala sekolah SMK BKTB memfasilitasi peningkatan kompetensi pedagogik maupun kompetensi profesional guru dengan mengirimkan guru pada pelatihan profesional yang relevan, karena pencapaian skorguru masih jauh dari standar kompetensi nasional ideal. Disamping itu kepala sekolah untuk melakukan supervisi pembelajaran secara berkelanjutan.

\section{DAFTAR RUJUKAN}

Almira, D., Dardiri, A., \& Isnandar. 2016. Kompetensi Lulusan SMK Program Keahlian Teknik Bangunan Kompetensi Teknik Konstruksi Batu dan Beton yang Dibutuhkan Industri Jasa Konstruksi di Jawa Timur. Jurnal Pendidikan: Teori
Penelitian, dan Pengembangan, 1(4): 674--680.

Bianome, W., Sonhadji, K.H., \& Purnomo. 2016. Hubungan Kemampuan Manajerial Kepala Sekolah, Motivasi Kerja, dan Iklim Organisasi dengan Profesionalisme Guru Produktif di SMK se-Kota Kupang. Tesis, PPS Universitas Negeri Malang.

BPS. 2015. Tingkat Pengangguran Terbuka (TPT) Sebesar 6,18 Persen. Online: https://www.bps.go.id/Brs/ view/id/1196, di akses pada Januari 2016.

Dardiri, A. 2015. Optimalisasi Kerjasama Praktik Industri Meningkatkan Citra dan Daya Saing SMK. Jurnal Pendidikan dan Pembelajaran, 22(2): 162--168.

Ernawati \& Marjono. 2007. Pengaruh Supervisi dan Disiplin Kerja terhadap Kinerja Guru. Jurnal Manajemen Sumberdaya Manusia, 2(1): $11--22$

Ghozali. 2004. Studi Peranan Pendidikan terhadap Pertumbuhan Ekonomi. Makalah disajikan dalam Seminar KONASPI. UNRAM. Lombok tanggal 15-16 September 2004.

Hadidjah, I. \& Kusumawardani, H. 2015. Pengaruh Media Animasi Pola Dasar Busana terhadap Motivasi Belajar Mahasiswa Tata Busana. Jurnal Teknologi dan Kejuruan, 28(2): 177--188.

Hariyanto, M., Mukhadis, A., \& Isnandar. 2012. Pembelajaran Kooperatif Tipe STAD untuk Meningkatkan Interaksi dalam Proses dan Hasil Belajar Mengefrais Roda Gigi Lurus pada Siswa SMK. 35(1): 37--46.

Khoiron, A.M. \& Sutadji, E. 2015. Pendidikan Karakter dan Lingkungan Sekolah terhadap Berpikir Kreatif serta Dampaknya pada Kompetensi Kejuruan. Jurnal Pendidikan dan Pembelajaran, 22(2): 103-116. 
Mahdiansyah. 2007. Kajian Hubungan Dunia Pendidikan dengan Dunia Industri. Puslitjaknov, (Online), (http://sippendidikan.org/media.php ?page $=$ detailkarya $\& i d=65, \quad$ diakses 11 Januari 2011).

Mendiknas RI. 2003. Undang-Undang RI. Nomor 20 tahun 2003 tentang Sistem Pendidikan Nasional. Jakarta: Mendiknas RI.

Mendiknas RI. 2005. Undang-undang RI Nomor 14 Tahun 2005 tentang Guru dan Dosen. Jakarta: Mendiknas RI.

Rahman, A. 2009. Pembinaan Kualitas Guru SMK (Kajian Kualitatif pada SMK di Bandung). Jurnal Tabularasa PPS UNIMED, 6(1): 14--26.

Safitri, A.R.A., Syafrudie, H.A., \& Sutrisno. 2012. Relevansi Program Studi Keahlian Teknik Bangunan dengan Pekerjaan Lulusan. Jurnal Teknologi dan Kejuruan, 35(1): 29-36.
Saud, S. 2009. Pengembangan Profesi Guru. Bandung: Alfabeta.

Sudira, P. 2012. Isu-isu Strategis Desentralisasi Pendidikan Kejuruan Indonesia. Makalah disajikan dalam Seminar Nasional ISPI. Yogyakarta 21-22 Januari 2012.

Sujianto, Mukhadis, A., \& Isnandar. 2012. Pengembangan Profesionalitas Berkelanjutan Guru Bersertifikat Guru SMK Rumpun. Jurnal Teknologi dan Kejuruan, 35(1): 1--16.

Sutrisno, Dardiri, A., \& Sugandi, R.M. 2016. Tingkat Ranah Penilaian pada Keahlian Teknik Batu dan Beton Sekolah Mengengah Kejuruan. Jurnal Ilmu Pendidikan, 22(2): 154-161.

Suyitno, Sonhadji, K.H., Arifin, I., \& Ulfatin, N. 2014. Entrepreneurial Leadership of Vocational Schools Principals in Indonesia. International Journal of Learning \& Development, 4(1): 45--64. 